\title{
ESL Student Perceptions of VLE Effectiveness at a University in South Korea
}

\author{
Gary Robinson \\ International College, The University of Suwon, South Korea \\ Lelanie M. Basco \\ International College, The University of Suwon, South Korea \\ Yolanda Mathews \\ International College, The University of Suwon, South Korea \\ Ricky Dancel \\ International College, The University of Suwon, South Korea \\ Maria Aurea Princena \\ International College, The University of Suwon, South Korea \\ Mark James Mc Keever \\ International College, The University of Suwon, South Korea
}

\begin{abstract}
The purpose of this study is to determine students' perception of the advantages, effects on language skills, suggestions for improvement, and limitations regarding the use of a VLE (Blackboard) and their differences according to gender, year, number of Blackboard courses taken, and computer literacy. The respondents of this study were 686 randomly selected university students enrolled in English classes at the University of Suwon in South Korea. An adapted survey questionnaire consisting of $\mathbf{3 3}$ items was administered to the students. The Mean was used to determine the students' perceptions in the four areas followed by t-test and ANOVA to determine the differences in the students' perceptions. The results showed that the students had a somewhat disagree rating in the areas of Advantages, Language, and Limitations and somewhat agree rating in the area of Suggestions. Significant differences were found in the students' perceptions in the four areas when grouped according to gender and computer literacy; a significant difference was found in the area of Limitations when grouped according to year; and no significant differences were found according to number of Blackboard courses taken.
\end{abstract}

Index Terms - E-learning, perceptions, effectiveness, LMS, VLE, blackboard, ESL

\section{INTRODUCTION}

In the area of educational technology, or e-learning, many different names are in use for the software tools which help to manage the learning process (Ahmed, et al., 2012, p. 88). Although some confusion exists with regard to the definition of such tools (JISC, 2006, p. 4), they generally combine some or all of these features and functions: communication tools e.g. email; collaboration tools, e.g. forums; creation of online courses and content; online assessment; and integration with school management information systems, e.g. student registration information (BECTA, 2004). Various commercial tools are available and where not referred to by specific name throughout this paper we use Virtual Learning Environment (VLE) to refer to the e-learning platform.

A full year of ESL classes is mandatory for all Korean university students. The prevalence of 'English Fever' in Korea has meant massive amounts of money are spent on learning it but with relatively poor scores achieved (Park, 2009, p. 51). The high education standards and student population density in Korea 'make investments in e-learning very cost-effective' (Lee, et al., 2009, p. 1327). Korean university students' attitudes towards learning English has been found to be generally positive (Geddes, 2016) but as ESL teachers at Korean universities mainly use teaching techniques 'separate from the technological reality that students live in' (Webster \& Son, 2015, p. 92), there is much potential to capitalize on students' attitudes and improve outcomes through the use of e-learning in ESL.

The University of Suwon (USW) introduced Blackboard Learn as the campus-wide VLE in the spring 2015 semester. The International College (IC) enthusiastically embraced the VLE for all ESL (English as a Second Language) classes, which are mandatory for all freshmen. Adoption by other departments and teachers has been slower. ESL classes are a mix of traditional "brick-and-mortar" teaching with the VLE used for sharing course documents, in-class materials and activities, and for hosting weekly online homework tests and midterm and final exams. The rationale for increased 
VLE-use for ESL classes includes improving student academic outcomes and standardizing a department-wide curriculum which would reduce teachers' preparation workloads and hopefully improve time efficiency and increase productivity within the IC department.

Some English-language elective classes in the IC and Korean-language courses in other departments also use Blackboard in different ways: traditionally taught classes where the VLE is used mainly to share resources and contact students; hybrid classes where students use the VLE for online lectures and other study resources before class while also attending some face-to-face classes; and online-only classes, where students use the VLE for online lectures and other study resources and communicate with the teacher and other students in online discussions. While an increase in the number of hybrid and online classes is planned, the effectiveness of the VLE should first be measured.

Across higher education, evaluation of the impact of institutions' VLEs on learners has become an established practice (UCISA, 2012, p. 11). As the use of VLEs has grown rapidly, an understanding of how such technologies are being used and their impact on users is vital (Heirdsfield, et al., 2011, p. 1). Evaluation is important as it 'provides feedback for course developers on teaching and learning and is an important part of quality assurance' (Dyson \& Campello, 2003, p. 11). Quality is a significant predictor of VLE usefulness and perceived satisfaction (Liaw, 2008) and if this cannot be assured, 'then online learning may be of little value' (Weaver, et al., 2008, p. 36). As such, this paper is a pilot in what will become a longitudinal study to justify the implementation of the e-learning platform, to assure quality, to gauge how to maximize its potential by evaluating its effectiveness in improving outcomes, by identifying barriers to usage, by measuring user satisfaction and by appraising its effects on learning and teaching methods. A critical factor in improving e-learning usage and effectiveness is to understand learners' attitudes towards it (Liaw, 2008, p. 865). Therefore, the main focus of this study will be on ascertaining student perceptions of its effectiveness. In so doing, this research will add to the literature on e-learning in higher education, particularly in Korean universities as work in this area was previously comparatively small (Lee, et al., 2009, p. 1327). Further interesting areas for research which were beyond the scope of this paper will be identified for future studies.

The research questions to be answered in this paper are as follows:

1. What is the students' overall perception of the advantages, effects on language skills, suggestions for improvement, and limitations regarding the use of Blackboard?

2. What are the students' perceptions of the advantages, effects on language skills, suggestions for improvement, and limitations regarding the use of Blackboard according to gender, year, number of Blackboard courses taken, and computer literacy?

3. Are there significant differences in the students' perception of the advantages, effects on language skills, suggestions for improvement, and limitations regarding the use of Blackboard when they were grouped according to gender, year, number of Blackboard courses taken, and computer literacy?

\section{LITERATURE REVIEW}

\section{A. Reasons for VLE Usage}

The quality of the VLE has received considerable attention in determining E-learning effectiveness. Factors regarding the VLE platform and its relation to E-learning effectiveness include VLE platform reliability, the value of VLE contents, VLE user-friendliness, and whether there is sufficient media (Wang, 2003).

In a longitudinal multi-institutional study surveying students' usage of a VLE, (Cosgrave, et al., 2011) (Risquez, et al., 2013), the main reason for usage was found to be sharing of course materials, such as lecture notes, with other uses, such as online discussions, quizzes and submitting assignments lagging far behind (Cosgrave, et al., 2011, p. 5). This study found that in general, students consider using a VLE to add value, with their satisfaction 'intrinsically linked with the educational design behind the use of the tools' (Risquez, et al., 2013, pp. 104-105). Although students viewed the VLE as 'an important aid to their learning and lectures not as a replacement', usage and satisfaction depended on the lecturers' ability or willingness to use it (Cosgrave, et al., 2011, p. 12). Lack of use of the VLE by the lecturer, rather than technical problems, was seen to be the most common barrier to student usage. Lecturers tend to use the VLE to solve specific problems, rather than to do new things (Risquez, et al., 2013, p. 103). Weaver, et al. (2008) noted a generally positive and satisfied VLE experience, with students believing that VLE effectiveness depended on how the teachers used it.

The importance of course content in determining high e-learning use and satisfaction was reported by Naveh at al. (2010). When used as a content repository, the VLE was still found to add value as a reliable, definitive curated repository of course material, providing students with a clear framework for the course' (Risquez, et al., 2013, p. 105). Poorly maintained courses and poor use of technology were concerns of students, highlighting the need for quality assurance in lending value to e-learning. However, it has been found that rather than being used simply as a content repository, VLEs could enhance learning skills when used as a 'communication, collaboration and knowledge-focused medium' (Lyndon \& Hale, 2014, p. 63).

While providing valuable insights, the survey in the longitudinal study mentioned above was conducted online and received low response rates. Students with high digital literacy were more likely to respond (Risquez, et al., 2013, p. 102), thereby limiting its effectiveness for measuring the effect of student computer literacy on VLE usage. Additionally, as it was carried out across entire student populations where VLE usage varies from class to class, it provides no 
evaluation of student perceptions on specific VLE learning outcomes. O'Sullivan found that just over half of the students surveyed were satisfied with the VLE with factors such as age, gender and level of computer literacy influencing usage and satisfaction (O’Sullivan, 2014), highlighting the importance of such variables.

\section{B. Student Perceptions and Influencing Variables}

A study of students at a university in Taiwan with two months' e-learning experience (Liaw, 2008) drew no results in terms of the measured variables of gender, field of study, internet experience and e-learning experience, but reported high correlations between system and multimedia quality, interactive learning activities and learners' self-efficacy and positive attitudes towards e-learning.

In a study of students' perceptions towards the use of Blackboard as a distance-learning tool, Al-mashaqbeh (2006) finds no significant correlation between students' gender, year of study and the kind of course being studied and their usage of the VLE. Her results showed students to be positive about the VLE as a delivery tool. Similarly, Fageeh (2011) also notes a lack of significant correlation between respondents' year of study and level of IT literacy in which learners' acceptance of e-learning was surveyed.

Keller \& Cernerud (2002) studied the perceptions of university students in Sweden with experience of at least two elearning courses and considered the variables gender, age, IT literacy, attitudes toward technology and learning styles. They found that students did not generally regard access to e-learning as a benefit and that the individual variables were less important than how the university implemented e-learning. Of the variables, there was no relationship of age or learning style to the students' perceptions, however women were more positive than men and students with lower IT literacy were more positive than those identifying themselves as early adopters. It may be worth nothing that since this study was done, technology has become a lot more common and widespread and as such, attitudes towards it may have changed.

Most learners in a survey of university students in the USA (Song, et al., 2004) perceived that the success of elearning depends on learner motivation, course design, time management and level of ease with internet technology. Challenges to e-learning's success were perceived to be technical problems, time constraints, a lack of community, and difficulties understanding online course objectives.

\section{E-learning in South Korea}

South Korea is one of the vanguard countries providing online education (ICEF Monitor, 2012) with almost 88 per cent of higher education institutes running an e-learning platform (Hwang, et al., 2010, p. 51). The results of a national poll found that for Korean students, e-learning is beneficial in terms of cost, time, system stability, and the diversity and quality of content as well as its effects on learning itself (Hwang, et al., 2010, p. 22). In a study investigating student satisfaction with blended learning at a university in South Korea, overall satisfaction was found to be high, with students shown to be very concerned with access to information, immediate feedback on assessments and ability to communicate with classmates and teachers and expressed varied preferences for traditional and blended learning depending on the type of class (Klemsen \& Seong, 2013, pp. 84-85).

The Korean Association of the University e-Learning Center (KAELC) conducted a survey assessing students' elearning satisfaction levels. Students' satisfaction rate was above average but not high. Overall results showed that students were more satisfied with E-learning design and operation and that female students were generally more satisfied than male students (Han, et al., 2013). Another study conducted by Woosong University in South Korea looked at student perceptions of learning English online. Half of the students responded that they preferred the online class over the offline class and learned better due to the greater flexibility offered regarding place and being able to learn at an individual pace (Lee, C.H. and Pyo, K.H., 2003).

Many Korean Universities have been given incentives and support by the Korean government to involve teachers in e-learning. One government-initiated program, 'E-Learning Content Development Program', provides financial and technical support to encourage content development. One study revealed that added financial and technical support resulted in higher training effectiveness and that this support came from superiors and the organization (Tracey at al., 2001). These types of support can equip teachers with the knowledge and expertise to overcome lack of use, which, as mentioned above, was seen to be the most common barrier to student usage.

\section{Methodology}

\section{A. Respondents}

The survey population consisted of 2,489 students taking ESL classes, the vast majority of whom are freshmen. The valid sample size of 686 is $27.5 \%$ of the population which ensures a margin of error of 0.0325 using Slovin's formula; a confidence level of almost $97 \%$.

As shown in Table I, the respondents of this study were the 686 randomly selected college students from The University of Suwon who were enrolled for the Spring Semester of the Academic Year 2016-2017. They were classified according to gender, year, number of Blackboard courses taken, and computer literacy. There were 304 (44.3\%) male and $382(55.79 \%)$ female; $584(85.1 \%)$ were freshmen, $54(7.9 \%)$ were sophomores, $29(4.2 \%)$ were juniors, and 19 $(2.8 \%)$ were seniors; $162(23.6 \%)$ had one Blackboard course taken, $281(41.0 \%)$ had two, $136(19.8 \%)$ had three, and 
$107(15.6 \%)$ had four or more; $154(22.4 \%)$ rated themselves not good in computer literacy, 297 (43.3\%) rated good, $120(17.5 \%)$ rated very good, and $115(16.8 \%)$ rated excellent.

TABLE I.

STUDENT PROFILE

\begin{tabular}{|l|l|l|}
\hline \multicolumn{2}{|l|}{ N } & $\%$ \\
\hline Total & 686 & $100 \%$ \\
\hline A. Gender & 304 & $44.3 \%$ \\
\hline Male & 382 & $55.7 \%$ \\
\hline Female & \multicolumn{2}{l|}{} \\
\hline B. Year & 584 & $85.1 \%$ \\
\hline Freshmen & 54 & $7.9 \%$ \\
\hline Sophomores & 29 & $4.2 \%$ \\
\hline Juniors & 19 & $2.8 \%$ \\
\hline Seniors & \multicolumn{2}{|l|}{} \\
\hline C. Blackboard Courses Taken & 162 & $23.6 \%$ \\
\hline One & 281 & $41.0 \%$ \\
\hline Two & 136 & $19.8 \%$ \\
\hline Three & 107 & $15.6 \%$ \\
\hline Four or more & \multicolumn{1}{|l|}{} \\
\hline D. Computer Literacy & 154 & $22.4 \%$ \\
\hline Not Good & 297 & $43.3 \%$ \\
\hline Good & 120 & $17.5 \%$ \\
\hline Very Good & 115 & $16.8 \%$ \\
\hline Excellent &
\end{tabular}

\section{B. Instrument}

Due to the low average level of responses to online surveys of 30 per cent (Dommeyer, et al., 2004), an anonymous paper questionnaire was used as the research instrument. This questionnaire was adapted from a study conducted by $\mathrm{Al}$ Zumor et al (2013) of ESL students at a university in Saudi Arabia and was divided into three parts. The first part contained 33 questions. These questions measured students' perceptions in four areas: advantages of using the VLE (10 items); effects of VLE usage on language skills (eight items); suggestions for improvement (six items); and limitations (nine items). Respondents were asked to rate each item on a Likert scale of six answers where $1=$ strongly disagree, $2=$ disagree, $3=$ somewhat disagree, $4=$ somewhat agree, $5=$ agree, and $6=$ strongly agree.

The second part asked questions about respondents' sex, year of study, number of courses taken using Blackboard, and computer literacy.

\section{Data Collection and Analysis}

The questionnaire was translated from English into Korean and 774 surveys were given to all ESL teachers to randomly distribute to students in their ESL classes between weeks 10 and 12 of semester one in 2016 when the freshman students had over two months' experience using the VLE. 712 surveys were returned, a completion rate of almost 92 per cent, of which 26 were invalid. The total of 686 valid surveys makes a completion rate of $96.3 \%$. Answers from the valid surveys were encoded, tabulated and interpreted using SPSS. For the interpretation of results in the areas of advantages of the VLE, effects on language skills, limitations of the VLE and suggestions for improving the VLE, the following scale and description were used:

\begin{tabular}{|l|l|}
\hline Value & Description \\
\hline $1.00-1.50$ & strongly disagree \\
\hline $1.51-2.50$ & disagree \\
\hline $2.51-3.50$ & somewhat disagree \\
\hline $3.51-4.50$ & somewhat agree \\
\hline $4.51-5.50$ & agree \\
\hline $5.51-6.00$ & strongly agree \\
\hline
\end{tabular}

\section{RESUltS AND DISCUSSION}

TABLE II.

STUDENTS’ PERCEPTION REGARDING THE USE OF BLACKBOARD

\begin{tabular}{|l|l|}
\hline Areas & Mean \\
\hline A. Advantages & 3.18 \\
\hline B. Language Skills & 3.25 \\
\hline C. Suggestions & 3.62 \\
\hline D. Limitations & 3.22 \\
\hline
\end{tabular}

The respondents gave a somewhat disagree rating in the areas of Advantages $(M=3.18)$, Language $(M=3.25)$, and 
Limitations $(M=3.22)$ and somewhat agree rating in the area of Suggestions $(M=3.62)$. Specifically, the top two items with the highest mean in the area of Advantages were question 7 (Mean=3.64), "Blackboard helps me to use time effectively." and question $5(\mathrm{M}=3.59)$, "Blackboard allows me to work at my own pace." Both had a somewhat agree rating. On the other hand, the two items with lowest ratings were question $2(\mathrm{M}=2.53)$, "Blackboard improves communication between students and teachers." and question $6(\mathrm{M}=3.03)$, "Blackboard helps me to develop knowledge of computers and the internet." Both items had a somewhat disagree rating. This means that students valued Blackboard with regards to time convenience. However, Blackboard does not help with teacher-student communication and knowledge development in the field of technology.

This result corroborates with the study of Lee, C. and Pyo, K. (2003) wherein half of the participants expressed favor for online classes because of its flexibility of place and they were able to work on their own pace. In this same study, students who favored offline classes found online classes to have not much interaction with the instructors.

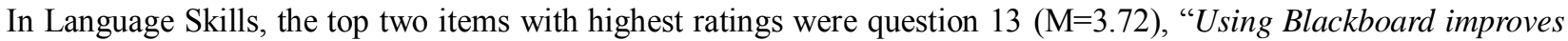
my reading skills." and question $11(\mathrm{M}=3.69)$, "Using Blackboard improves my listening skills." On the other hand, the two items with lowest ratings were question $15(\mathrm{M}=2.48)$, "Using Blackboard improves my pronunciation." and question $12(\mathrm{M}=2.62)$, “Using Blackboard improves my speaking skills." This means that the students' reading and listening skills were enhanced by Blackboard use. However, their pronunciation and speaking skills were apparently not improved since there was no interaction in the Blackboard activities.

This result is supported by the study of Lee and Pyo (2003) where Korean students enrolled in English classes found online classes to be helpful in developing their listening skills because they could repeat the listening lessons whenever needed and when they were interested.

In the area of Suggestions, the top two items with the highest ratings were question $21(\mathrm{M}=4.58)$, "All technical problems should be solved as early as possible." and question $20(\mathrm{M}=4.23)$, "The number of places to access computers should be increased." On the other hand, the two items with lowest ratings were question 19 (M=2.56), "I would like to see an increase in the number of Blackboard courses." and question $24(\mathrm{M}=2.82)$, "Those that prove themselves as distinguished users of Blackboard should be rewarded." This means that while technical difficulties, including accessibility of computers, was the students' foremost problem in using Blackboard, they did not want to have more Blackboard courses offered or rewards given to distinguished Blackboard users.

In the area of Limitations, the top two items with the highest ratings were question 31 ( $\mathrm{M}=3.97)$, "Using the interaction tools on Blackboard is less effective than face-to-face interaction in the classroom." and question 30 $(\mathrm{M}=3.95)$, "Blackboard facilitates cheating and plagiarism." On the other hand, the two items with lowest ratings were question 32 (M=1.99), "I do not have a computer and therefore I find it difficult to use Blackboard." and question 25 $(\mathrm{M}=2.56)$, "I feel isolated from other students when I use Blackboard." This means that the students found Blackboard to be a hindrance to classroom interaction between and among teachers and students and it allows students to cheat and plagiarize. In addition, having no computer and experiencing feelings of isolation when using Blackboard were the least important limitations for students.

The study of Lee and Pyo (2003) supported the above result where several students had a preference for offline classes in terms of interactions and classroom activities. Teachers who were involved in the study revealed a constant problem in online classes where students just copied assignments from their classmates or just cut and pasted other's work.

TABLE III.

STUDENTS’ PERCEPTION REGARDING THE USE OF BLACKBOARD ACCORDING TO GENDER

\begin{tabular}{|c|c|c|c|c|}
\hline Category & Advantages & Language Skills & Suggestions & Limitations \\
\hline Total & 3.18 & 3.25 & 3.62 & 3.22 \\
\hline Male & 3.41 & 3.43 & 3.80 & 3.11 \\
\hline Female & 3.00 & 3.11 & 3.48 & 3.31 \\
\hline
\end{tabular}

When grouped according to gender, both male and female gave a mean rating of somewhat disagree in the areas of Advantages, Language and Limitations. Within these individual areas, male students' rating was higher than that of female students in the areas of Advantages $(M=3.41$ versus $M=3.00)$ and Language Skills $(M=3.43$ versus $M=3.11)$ but female students' rating $(\mathrm{M}=3.31)$ was higher than that of male students $(\mathrm{M}=3.11)$ in the area of Limitations. In the area of Suggestions, the two groups' ratings differed, as male students somewhat agreed $(\mathrm{M}=3.80)$ while female students somewhat disagreed $(\mathrm{M}=3.48)$. This means that male students perceived that Blackboard had more advantages and was helpful in improving their language skills. On the other hand, female students perceived the use of Blackboard as having more limitations. In a study examining female student perceptions regarding e-Learning, Kibello, Y. and Bao, M. (2014) noted key concerns raised over the issues of lack of face-to-face interaction and lack of motivation in the online environment. Important issues and recommendations are raised for consideration when promoting e-learning programs.

A study conducted by the Korean Association of the University e-Learning Center (KAELC) corroborated this result in that female students were generally more satisfied than male students (Han, et al., 2013). 
TABLE IV.

T-TEST BETWEEN GENDERS

\begin{tabular}{|l|l|l|l|}
\hline Areas & t-value & Df & Sig. \\
\hline Advantages & 5.03 & 654 & $0.00^{*}$ \\
\hline Language Skills & 3.83 & 630 & $0.00^{*}$ \\
\hline Suggestions & 4.65 & 625 & $0.00^{*}$ \\
\hline Limitations & -2.84 & 649 & $0.00^{*}$ \\
\hline
\end{tabular}

The results of an independent-samples t-test show that when the students were grouped according to gender, there were significant differences in each of the four areas. This suggests that male and female respondents had different opinions on the advantages of using the VLE, effects on language skills of using the VLE, suggestions for improving the use of the VLE, and on the limitations of using the VLE.

TABLE V.

STUDENTS' PERCEPTION REGARDING THE USE OF BLACKBOARD ACCORDING TO YEAR

\begin{tabular}{|l|l|l|l|l|}
\hline Category & Advantages & Language Skills & Suggestions & Limitations \\
\hline Total & 3.18 & 3.25 & 3.62 & 3.22 \\
\hline Freshmen & 3.20 & 3.28 & 3.62 & 3.18 \\
\hline Sophomores & 3.00 & 2.98 & 3.47 & 3.60 \\
\hline Juniors & 3.23 & 3.27 & 3.83 & 3.11 \\
\hline Seniors & 3.12 & 2.97 & 3.82 & 3.63 \\
\hline
\end{tabular}

The results in Table $\mathrm{V}$ show that, according to year, students in all level gave a somewhat agree rating in the areas of Advantages and Language Skills. In the area of Suggestions, three levels gave a somewhat agree rating except for sophomores who gave a somewhat disagree rating. In the area of Limitations, sophomores and seniors gave a somewhat agree rating while freshmen and juniors gave a somewhat disagree rating. This tells us that students find blackboard learning less effective than traditional, face-to-face learning, however, granted the provision of proper training, technical assistance and availability of on-campus computers, they are interested in seeing an increase in the number of blackboard courses offered.

The most notable mention is regarding the area of Language Skills. Freshmen students scored the highest while seniors scored the lowest. This could be attributed to differences in second-language proficiency and/or level of exposure to VLE-type classes. Also, freshman may have a more optimistic view and comfort level with using computers in an online learning environment than seniors. The results of a study conducted in the Netherlands concluded that younger students were more optimistic about using information communication technologies in their lessons than older students (Kubiatko \& Haláková, 2009). However, in a study of Korean university students done by Lee and Pyo (2003), it was concluded that freshmen students enrolled in English classes found online learning to be burdensome compared with the students in a higher level.

It is also worth mentioning that in the Limitations area, seniors scored the highest. This could also be because the older senior students may be less comfortable and technologically adept to VLE learning than the younger students, who had probably begun developing greater digital literacy at a younger age. Several studies point to year and age of study as an indicator of success in computer-based learning, showing that younger individuals and students are simply more familiar with computer-based technologies (Zickuhr \& Madden, 2012); (Greenhow, et al., 2009).

TABLE VI.

ANOVA ACCORDING TO YEAR

\begin{tabular}{|l|l|l|l|l|l|}
\hline Sources of Variation & Sum of Squares & Df & Mean Square & F & Sig. \\
\hline Advantages & & & & & \\
\hline Between Groups & 2.210 & 3 & .737 & 0.63 & 0.59 \\
\hline Within Groups & 788.220 & 682 & 1.156 & & \\
\hline Language Skills & & & & \\
\hline Between Groups & 6.054 & 3 & 2.018 & 1.68 & 0.17 \\
\hline Within Groups & 818.899 & 682 & 1.201 & & \\
\hline Suggestions & & & & 1.40 & \\
\hline Between Groups & 3.400 & 3 & 1.133 & & 0.24 \\
\hline Within Groups & 552.083 & 682 & .810 & & \\
\hline Limitations & & 3 & & 4.62 & \\
\hline Between Groups & 12.371 & 682 & .891 & & $0.00^{*}$ \\
\hline Within Groups & 607.925 & & \\
\hline
\end{tabular}

When students were grouped according to year, the ANOVA results showed a significant difference in the area of Limitations, however no significant differences were found in the areas of Advantages, Language, or Suggestions. This means that there were differences in how freshmen, sophomores, juniors, and seniors perceived the limitations of using blackboard, but no differences in how they perceived the advantages, language, and suggestions of using blackboard. Furthermore, these results showed that the students' year affected their perception of the limitations of using blackboard but did not affect their perception of the advantages, language, and suggestions of using blackboard. Low significance values may be attributed to the fact that a clear majority of these students have had limited exposure to and experience 
with VLE learning and are not fully receptive to learning English on Blackboard.

TABLE VII.

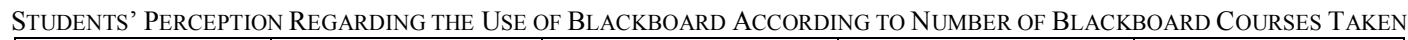

\begin{tabular}{|l|l|l|l|l|}
\hline Category & Advantages & Language Skills & Suggestions & Limitations \\
\hline Total & 3.18 & 3.25 & 3.62 & 3.22 \\
\hline One & 3.24 & 3.30 & 3.58 & 3.25 \\
\hline Two & 3.13 & 3.17 & 3.60 & 3.22 \\
\hline Three & 3.23 & 3.34 & 3.70 & 3.25 \\
\hline Four Plus & 3.18 & 3.27 & 3.62 & 3.15 \\
\hline
\end{tabular}

The results in Table VII show that the students in all four categories gave a somewhat disagree rating in the areas of advantages, language skills, and limitations. This means that the students perceived the use of Blackboard as not so advantageous and helpful in improving their language skills and has few limitations. On the other hand, in the area of suggestions, the students in all four areas gave a somewhat agree rating which means that they perceived a need for the Blackboard use to be improved. A somewhat related study conducted at Tamk University of Applied Sciences in Finland revealed that 'prior E-learning experience significantly correlates with perceived E-learning effectiveness, E-learning productivity and amount of learning' (Haverila, 2011).

TABLE VIII.

ANOVA ACCORDING TO BLACKBOARD COURSES TAKEN

\begin{tabular}{|c|c|c|c|c|c|}
\hline Sources of Variation & Sum of Squares & Df & Mean Square & $\mathrm{F}$ & Sig. \\
\hline \multicolumn{6}{|l|}{ Advantages } \\
\hline Between Groups & 1.682 & 3 & .561 & .485 & .693 \\
\hline Within Groups & 788.748 & 682 & 1.167 & & \\
\hline \multicolumn{6}{|l|}{ Language Skills } \\
\hline Between Groups & 3.232 & 3 & 1.077 & .894 & .444 \\
\hline Within Groups & 821.721 & 682 & 1.205 & & \\
\hline \multicolumn{6}{|l|}{ Suggestions } \\
\hline Between Groups & 1.367 & 3 & .456 & .561 & .641 \\
\hline Within Groups & 554.116 & 682 & .812 & & \\
\hline \multicolumn{6}{|l|}{ Limitations } \\
\hline Between Groups & .805 & 3 & .268 & .296 & .829 \\
\hline Within Groups & 619.491 & 682 & .908 & & \\
\hline
\end{tabular}

When students were grouped according to the number of Blackboard courses taken, the ANOVA results show that there was no statistically significant differences for the areas of advantages of using the VLE, effects on language skills, suggestions for improving the VLE, or limitations of using the VLE. This may suggest that regardless of their experience of using Blackboard, they perceived the advantages, effects on language skills, and limitations of Blackboard to be the same. It may also suggest that they also provide similar suggestions and recommendations for improving the use of Blackboard.

TABLE IX.

STUDENTS' PERCEPTION REGARDING THE USE OF BLACKBOARD ACCORDING TO COMPUTER LITERACY

\begin{tabular}{|l|l|l|l|l|}
\hline Category & Advantages & Language Skills & Suggestions & Limitations \\
\hline Total & 3.18 & 3.25 & 3.62 & 3.22 \\
\hline Not Good & 2.86 & 2.96 & 3.35 & 3.66 \\
\hline Good & 3.18 & 3.23 & 3.57 & 3.18 \\
\hline Very Good & 3.36 & 3.31 & 3.88 & 3.11 \\
\hline Excellent & 3.44 & 3.63 & 3.84 & 2.87 \\
\hline
\end{tabular}

The result shows that when the students were grouped according to computer literacy, all respondents in four categories namely: not good, good, very good, and excellent gave a somewhat disagree rating in the area of advantages; the respondents gave the same rating in the area of language skills except those who belong to the excellent category who gave a somewhat agree rating; in the area of suggestions the respondents gave a somewhat agree rating except for those who belong to the not good category who gave a somewhat disagree rating; and in the area of limitations the respondents gave a somewhat disagree rating except for those who belong to the not good category who gave a somewhat agree rating.

This means that when it comes to computer literacy, students who rated themselves as not good, somewhat disagreed that Blackboard use is advantageous in learning, is helpful in improving their language skills, and should be improved, however, they somewhat agreed that Blackboard use has a lot of limitations. The students who rated themselves as good and very good, somewhat disagreed that Blackboard use is advantageous in learning, is helpful in improving their language skills, and has a lot of limitations, however, they somewhat agreed that Blackboard should be improved. The students who rated themselves as excellent, somewhat disagreed that Blackboard use is advantageous in learning and has a lot of limitations and somewhat agreed that Blackboard use is helpful in improving their language skills and should be improved. 
TABLE X.

ANOVA ACCORDING TO COMPUTER LITERACY

\begin{tabular}{|l|l|l|l|l|l|}
\hline Sources of Variation & Sum of Squares & Df & Mean Square & F & Sig. \\
\hline Advantages & & & & & \\
\hline Between Groups & 26.733 & 3 & 8.911 & 7.958 & $.000^{*}$ \\
\hline Within Groups & 763.698 & 682 & 1.120 & & \\
\hline Language Skills & & & & & \\
\hline Between Groups & 29.905 & 3 & 9.958 & 8.551 & $.000^{*}$ \\
\hline Within Groups & 795.048 & 682 & 1.166 & & \\
\hline Suggestions & & & & & 10.802 \\
\hline Between Groups & 25.198 & 3 & 8.399 & & $.000^{*}$ \\
\hline Within Groups & 530.285 & 682 & .778 & & \\
\hline Limitations & & & & 18.215 & $.000^{*}$ \\
\hline Between Groups & 45.013 & 3 & 16.338 & & \\
\hline Within Groups & 574.283 & 682 & .842 & & \\
\hline
\end{tabular}

When students were grouped according to computer literacy, the ANOVA result showed significant differences existed in all four areas. This means that the students' computer literacy level affects their perception on the advantages of using the VLE, effects on language skills of using the VLE, their suggestions for improving the use of the VLE, and the limitations of using the VLE.

This would corroborate Northrup's study (2001) which suggested that learner engagement is higher with interactive communication and multimedia instruction: higher interactivity can lead to higher learner engagement and better learning outcomes but a lower level of computer literacy would also likewise adversely affect interactive communication and multimedia instruction. Students see the convenience Blackboard brings and how it makes the class more interesting and useful.

\section{CONCLUSION}

\section{A. Conclusions}

This study aimed to examine students' perceptions of the use of Blackboard and the following conclusions were advanced:

First, in using Blackboard, the students' perceptions of the advantages, effects on language skills, and limitations were somewhat disagree and their perception of the suggestions was somewhat agree. Specifically, Blackboard was perceived by the students to be helpful in their use of time, independent work, and in improving their reading and listening skills. On the other hand, Blackboard does not facilitate classroom interaction and it provides the possibility for students to plagiarize and cheat.

Second, when grouped according to gender, male students perceived the use of Blackboard as more advantageous and helpful while female students perceived it as having more limitations and agreed that improvements in Blackboard use should be made. Significant differences in the students' perception of Blackboard use were found in all four areas.

Third, when grouped according to year, students had varied ranks in each area and a significant difference in their perceptions was found only in the area of limitations.

Fourth, when grouped according to number of Blackboard courses taken, students who took three or more Blackboard courses perceived Blackboard to be more useful and helpful. No significant difference was found in the four areas.

Fifth, when grouped according to computer literacy, students found the use of Blackboard as not so advantageous, not so helpful in improving their language skills, needing improvement and having a few limitations. Significant differences in the students' perception of Blackboard use were found in all four areas.

\section{B. Limitations and Suggestions}

Below is the outline of some limitations of this study and suggestions for how these can be improved upon in the future.

The questionnaire only featured statements where the students have to rate their perceptions. Open-ended questions could be added to the questionnaire followed by focus group discussions with respondents in order to ascertain reasons for answers given in the questionnaire and to enhance the quantitative results by including a qualitative aspect.

This study surveyed student perceptions only and not actual learning outcomes. A better idea of VLE effectiveness could be obtained by measuring learning outcomes and comparing to those of non-Blackboard ESL classes. As all ESL classes use Blackboard, a control group would need to be set up.

It may be of value to extend this research into a longitudinal analysis and to seek collaboration with other universities, both inside and outside Korea, in order to provide and gain meaningful insights into sector-wide trends and best practices.

\section{REFERENCES}

[1] Ahmed, A. A., Zakaria, N. H. \& Elmi, A. H. (2012). An evaluation of Virtual learning Environment Readiness in Higher 
Institutions (HEIs). Journal of Information Systems Research and Innovation, 2, 86-94.

[2] Al Zumor, A. W. Q., Al Refaai, I. K., Bader Eddin, E. A. \& Aziz Al-Rahman, F. H. (2013). EFL Students' Perceptions of a Blended Learning Environment: Advantages, Limitations and Suggestions for Improvement. English Language Teaching, 6(10), 95-110. doi: 10.5539/elt.v6n10p95.

[3] Al-Mashaqbeh, I., (2006). Students Perception Toward the Use of Blackboard as a Course Delivery Method. http://econf.uob.edu.bh/confl/pdf\%20files/77.pdf (accessed 3/5/2017).

[4] BECTA, (2004). What the research says about Virtual Learning Environments in teaching and learning. http://archive.teachfind.com/becta/research.becta.org.uk/upload-dir/downloads/page_documents/research/wtrs_vles.pdf (accessed 3/11/2015).

[5] Cosgrave, R. et al., (2011). Usage and Uptake of Virtual Learning Environments in Ireland: Findings From a Multi-Institutional Study. AISHE-J, 3(1), 30.1-30.14.

[6] Dommeyer, C. J., Baum, P., Hanna, R. W. \& Chapman, K. S., (2004). Gathering faculty teaching evaluations by in-class and online surveys: Their effects on response rates and evaluations. Assessment \& Evaluation in Higher Education, 29(5), 611-23.

[7] Dyson, M. C. \& Campello, S. B., (2003). Evaluating Virtual Learning Environments: what are we measuring? Electronic Journal of e-Learning, 1(1), 11-20.

[8] Fageeh, A. I., (2011). EFL students' readiness for e-learning: factors influencing e-learners' acceptance of the Blackboard in a Saudi university. The JALT CALL Journal, Volume 1, 19-42.

[9] Geddes, A. J., (2016). Korean University Students' Attitudes and Motivation towards Studying English. Universal Journal of Educational Research, 4(4), 04-715. doi:10.13189/ujer.2016.040407.

[10] Greenhow, C., Robelia, B. \& Hughes, J. E. (2009). Learning, Teaching, and Scholarship in a Digital Age - Web 2.0 and Classroom Research: What Path Should We Take Now? Educational Researcher, 38(4), $246-259$. doi:10.3102/0013189X09336671.

[11] Han, I., Keun. Y., \& Lee, K. (2013). Promoting E-learning in University Education in Korea: The Role of Regional University E-learning Centers. International Journal of Contents, 9(3), 35-41. doi:10.5392/IJoC.2013.9.3.035.

[12] Haverila, M., (2011). Prior E-learning Experience and Perceived Learning Outcomes in an Undergraduate E-learning Course. MERLOT Journal of Online Learning and Teaching, 7(2), 206-218.

[13] Heirdsfield, A., Walker, S., Tambyah, M. \& Beutel, D. (2011). Blackboard As An Online Learning Environment: What Do Teacher Education Students And Staff Think? Australian Journal of Teacher Education, 36(7), 1-16. doi:10.14221/ajte.2011v36n7.4.

[14] Hwang, D. J., Yang, H.-K. \& Kim, H., (2010). E-Learning in the Republic of Korea. http://iite.unesco.org/pics/publications/en/files/3214677.pdf (accessed 4/11/2015).

[15] ICEF Monitor, (2012). 8 countries leading the way in online education. http://monitor.icef.com/2012/06/8-countries-leadingthe-way-in-online-education/ (accessed 4/11/2015).

[16] JISC, (2006). Effective Use of VLEs: Introduction to VLEs. http://tools.jiscinfonet.ac.uk/downloads/vle/what-is-vle.pdf (accessed 4/11/2015).

[17] Keller, C. \& Cernerud, L. (2002). Students' Perceptions of E-learning in University Education. Journal of Educational Media, 27(1-2), 55-67. doi:10.1080/1358165020270105.

[18] Kibelloh, M. \& Bao, Y. (2014). Perceptions of International Female Students Towards E-learning in Resolving High Education and Family Role Strain. Journal of Educational and Computing Research, 50(4). doi:10.2190/EC.50.4.b.

[19] Klemsen, K. M. \& Seong, M. H., (2013). Reflection on the Use of Blended Learning at a Korean University. Pan-Pacific Association of Applied Linguistics, 16(2), 69-87.

[20] Kubiatko, M. \& Haláková, Z., (2009). Slovak high school students' attitudes to ICT using in biology lesson. Computers in Human Behavior, 25(3), p. 743-748. doi:10.1016/j.chb.2009.02.002.

[21] Lee, B.-C., Yoon, J.-O. \& Lee, I. (2009). Learners' acceptance of e-learning in South Korea: Theories and results. Computers \& Education, Volume 53, p. 1320-1329. doi:10.1016/j.compedu.2009.06.014.

[22] Lee, C.-H. \& Pyo, K.-H.m. (2003). A study on the effectiveness of online/offline English language learning at university level. Multimedia-Assisted Language Learning, 6(1), 90-110.

[23] Liaw, S.-S. (2008). Investigating students' perceived satisfaction, behavioral intention, and effectiveness of e-learning: A case study of the Blackboard system. Computers \& Education, Volume 51, 864-873. doi:10.1016/j.compedu.2007.09.005.

[24] Lyndon, S. \& Hale, B. (2014). Evaluation of How the Blended Use of a Virtual Learning Environment (VLE) Can Impact on Learning and Teaching in a Specific Module. ELiSS, 6(1), 56-65. doi:10.11120/elss.2014.00019.

[25] Naveh, G., Tubin, D. \& Pliskin, N., (2010). Student LMS use and satisfaction in academic institutions: The organizational perspective. Internet and Higher Education, Volume 13, 127-133. doi:10.1016/j.iheduc.2010.02.004.

[26] Northrup, P. (2001) A Framework for Designing Interactivity into Web-based Instruction. Educational Technology, 41(2), 31-39.

[27] O'Sullivan, P. (2014). An Evaluation of Virtual Learning Environment Design and a Comparison of Student's Requirements. http://commerce3.derby.ac.uk/ojs/index.php/da/article/download/47/55 (accessed 4/11/2015).

[28] Park, J.-K., (2009). 'English fever' in South Korea: its history and symptoms. English Today, 25(01), 50-57. doi:10.1017/S026607840900008X

[29] Risquez, A. et al. (2013). An Investigation of Students' experiences of using virtual Learning environments: implications for academic professional development. In: C. O'Farrell \& A. Farrell (eds.), Emerging Issues in Higher Education III: From capacity building to sustainability. Athlone: EDIN, 99-112.

[30] Song, L., Singleton, E. S., Hill, J. R. \& Koh, M. H. (2004). Improving online learning: Student perceptions of useful and challenging characteristics. Internet and Higher Education, Volume 7, 59-70. doi:10.1016/j.iheduc.2003.11.003.

[31] Tracey, J.B., T.R. Hinkin, S. Tannenbaum, and J.E. Mathieu. (2001). The influence of individual characteristics and the work environment on varying levels of training outcomes. Human Resource Development Quarterly 12(1) 5-23. doi:10.1002/15321096(200101/02)12:1<5::AID-HRDQ2>3.0.CO;2-J.

[32] UCISA, (2012). 2012 Survey of Technology Enhanced Learning for higher education in the UK. 
http://www.ucisa.ac.uk/ /media/groups/ssg/surveys/TEL_survey_2012_with\%20Apps_final.ashx (accessed 3/11/2015).

[33] Wang, Y. (2003). Assessment of learner satisfaction with asynchronous electronic learning systems. Information \& Management, 41(1), 75-86. doi:10.1016/S0378-7206(03)00028-4.

[34] Weaver, D., Spratt, C. \& Nair, C. S. (2008). Academic and student use of a learning management system: Implications for quality. Australasian Journal of Educational Technology, 24(1), 30-41. doi:10.14742/ajet.1228.

[35] Webster, T. E. \& Son, J.-B., (2015). Doing what works: A grounded theory case study of technology use. Computers \& Education, 80, 84-94. doi:10.1016/j.compedu.2014.08.012.

[36] Zickuhr, K. \& Madden, M. (2012). Older adults and internet use. http://www.pewinternet.org/files/oldmedia/Files/Reports/2012/PIP_Older_adults_and_internet_use.pdf (accessed 3/5/2017).

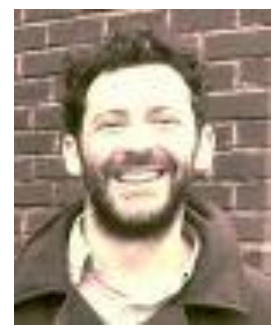

Gary Robinson is from Dublin, Ireland. He has an MA in global political economy from the University of Sussex, United Kingdom from which he graduated in 2012.

$\mathrm{He}$ is currently working as an Academic Technologist in the Politics and International Studies department at the University of Warwick, United Kingdom. He previously worked as an Assistant Professor in the International College at the University of Suwon, South Korea.

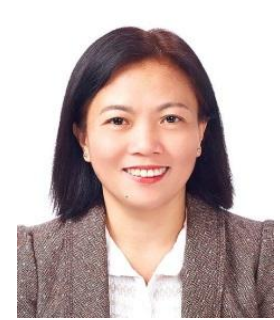

Lelanie M. Basco is from the Philippines. She finished her Bachelor of Elementary Education in 1991; Master of Arts in Education in 2001; and Master of Education in special education in 2009 from West Visayas State University, Iloilo City, Philippines. She earned her Doctor of Philosophy in Education major in psychology and guidance degree in 2006 from the University of San Agustin in the same city.

She taught in the Philippines in the following institutions: Assumption-Iloilo as a Classroom Teacher from 1992 to 2001; at the University of San Agustin as an Assistant Professor from 2001 to 2012 and at Saint Pedro Poveda College as a College Instructor from 2012-2014. She was an Assistant Professor at Gyeongju University in South Korea for one year (2014-2015). Presently, she is in her third year as an Assistant Professor in the International College of The University of Suwon in South Korea. Her research interests focus on the factors that affect teaching and learning and on curriculum development.

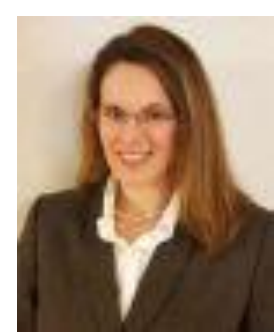

Yolanda Mathews is from the United States. She has a BA in Finance from the University of Toledo and an MBA from the University of North Carolina. She is a PhD candidate focusing on Management.

She is currently in her fifth year as an Assistant Professor in the International College at the University of Suwon in South Korea. She is also the Assistant Director of the International College Online Education Department and teaches undergraduate students business, negotiation, and English.

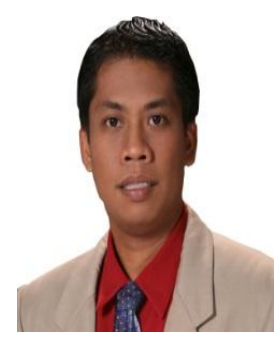

Ricky Dancel was born on March 7, 1978 in the province of Roxas, Isabela in the Philippines. In 2000, he obtained his Bachelor's degree in Secondary Education Major in Physics from the Best Teacher Education Institution in the Philippines, the Philippine Normal University. Throughout the university, he was a fulltime scholar of the Commission of Higher Education in the Philippines. He completed his Masters of Education degree Major in Administration and Supervision in Laguna College of Business and Arts in 2008.

Maria Aurea Princena is from the Philippines. She has a Master's degree in Management, major in School Management. She has been teaching at the university level for 19 years. She is currently connected to the International College of the University of Suwon. 


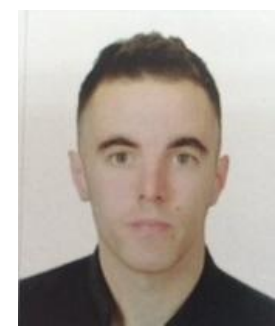

Mark James Mc Keever was born in Dublin April $4^{\text {th }} 1989$. Double Honours Bachelor of Arts degree in history and geography, National University of Ireland Maynooth, Maynooth, Co.Kildare, Ireland, 2009. Masters degree in military history and strategic studies, National University of Ireland Maynooth, Maynooth, Co.Kildare, Ireland, 2010.

He is currently an Assistant Professor at Dharma College Foreign Language Center in Dongguk University, Seoul, South Korea. He previously worked as an Assistant Professor at Suwon University and Kyungil University. He also previously worked as a middle school teacher at Osung Middle School. 